\title{
Influence of stage of maturity on bromatological quality of corn forage
}

\author{
Alano Xavier Souza Filho ${ }^{1}$, Renzo Garcia Von Pinho ${ }^{1}$, José Luiz de Andrade Resende \\ Pereira $^{1}$, Matheus Costa dos Reis ${ }^{1}$, Adauton Vilela de Rezende ${ }^{2}$, Diego de Castro Mata ${ }^{1}$ \\ 1 Universidade Federal de Lavras, Caixa Postal 37, 37200-000, Lavras, MG. \\ 2 Universidade José do Rosário Vellano, Alfenas, MG.
}

\begin{abstract}
The objective of this study was to evaluate the effects of stalk/leaf ratio and the stage of maturity on the digestibility of the corn plant. Hybrids AG1051, AG4051, AG5011, DOW2B710, DOW2C577, DOW2A525, NB7315 and P30F90 were used, harvested at the one-half milk line $(1 / 2 \mathrm{ML})$, three-quarters milk line $(3 / 4 \mathrm{ML})$ and black layer (BL) stages. A randomized block design was used in an 8 (hybrids) $\times 3$ (stages of maturity) factorial design, with three replications. The means generated were used for grouping into high and low stalk/leaf ratio and a new analysis of variance was generated in a $2 \times 3$ (two groups and three stages of maturity) factorial design. The whole plant and its stalk, leaf, husk, cob and grain components were incubated in situ in the rumen of three cows for determination of degradability of dry matter and degradable neutral detergent fiber. Stalk/leaf ratio did not influence neutral detergent fiber content or the degradability of dry matter and neutral detergent fiber of any of the components, except for the cob, in which the high ratio group had greater degradable neutral detergent fiber contents. There was a reduction in the degradability of all the parts, except for the stalk and cob, and an increase in the neutral detergent fiber contents of the vegetative parts, except for the stalk. Unlike the vegetative components, the neutral detergent fiber contents of the whole plant decreased throughout the stages evaluated. For degradable neutral detergent fiber, there was a reduction in the whole plant and in its components. The advance of maturity reduces the quality of the vegetative components; however, this loss in the entire plant is moderated by grain filling. Forage quality depends more on the quality of the components than on their proportions in the dry matter.
\end{abstract}

Key Words: degradable NDF, forage digestibility, ruminal degradability, silage

\section{Introduction}

The evolution of livestock raising requires intensive production systems in which the use of high quality forages throughout the year is fundamental. The high energy value of the corn plant favors its use in creating silages and may contribute to reduction in use of feed concentrates and feed cost.

Due to the greater proportion of grain in dry matter (DM) of corn forage, for a long time it was believed that greater yield of this component would also confer better quality to silage (Allen et al., 2003). Nevertheless, the digestibility of the bulky part must also be evaluated in the process of determining the quality of the material to be silaged. This approach becomes even more important considering that the stalk, leaf, husk and cob parts add up to nearly $65 \%$ of the total DM of the plant, and contribute with nearly $35 \%$ to in vitro digestibility of the whole plant, which represents nearly $65 \%$ of the potential digestibility of this plant (Hunt et al., 1998; Nussio, 1992). However, few studies show the effective importance of the vegetative parts on the quality of the forage to be ensiled (Hunt et al., 1998).

Ballard et al. (2001) emphasized the superior forage of materials with a greater proportion of leaves as compared to hybrids with a greater percentage of stalk. American hybrids for silage with leafy genes (greater number of leaves above the ear) and brown midrib showed better fiber quality and greater digestibility of the entire plant (Clark et al., 2002).

Other forms of variation in forage quality are the effects of climate and, especially, plant maturity. With advancing maturity, there may be a reduction in the proportion of vegetative components and loss in the quality of the bulky part and of starch. Less accentuated losses have been reported in leafy materials, which showed greater grain filling, without the loss of plant's moisture, thus increasing the optimal cutting period and the nutritional value of the silage (Ma et al., 2006).

Most studies related to the quality of the vegetative components are about hybrids of temperate climate. There are few studies on the influence of the proportion of 
vegetative components on forage quality for tropical hybrids. This study was performed with the objective of evaluating the effect of the stage of maturity of the corn plant at the harvest time on the bromatological quality of the whole plant and of the structural components of corn hybrids with different stalk/leaf ratios.

\section{Material and Methods}

The study was carried out in a soil classified as Hapludox / Dystroferric Red Latosol, of clayey texture and $9 \%$ slope, with the following composition in the 0 to $20 \mathrm{~cm}$ layer: $\mathrm{pH}$ in water $=5.2$; organic matter $=3.0 \mathrm{~g} / \mathrm{dm}^{3}$; potassium $=190 \mathrm{mg} / \mathrm{dm}^{3} ;$ calcium $=2.0 \mathrm{cmol}_{\mathrm{c}} / \mathrm{dm}^{3} ;$ magnesium $=0.6 \mathrm{cmol}_{\mathrm{c}} / \mathrm{dm}^{3}$; aluminum $=0.1 \mathrm{cmol}_{\mathrm{C}} / \mathrm{dm}^{3}$; $\mathrm{H}+\mathrm{Al}=5.6 \mathrm{cmol}_{\mathrm{c}} / \mathrm{dm}^{3} ; \mathrm{V}=45.4 \% ; \mathrm{M}=3.1 \%$; phosphorus = $10.3 \mathrm{mg} / \mathrm{dm}^{3}$; $\mathrm{B}=0.3 \mathrm{mg} / \mathrm{dm}^{3}$; copper $=3.1 \mathrm{mg} / \mathrm{dm}^{3}$; iron = $42.1 \mathrm{mg} / \mathrm{dm}^{3} ;$ manganese $=11.8 \mathrm{mg} / \mathrm{dm}^{3} ;$ zinc $=5.1 \mathrm{mg} / \mathrm{dm}^{3}$; clay $=570 \mathrm{~g} / \mathrm{kg}$; silt $=8 \mathrm{~g} / \mathrm{kg}$; sand $=35 \mathrm{~g} / \mathrm{kg}$.

Climate in the region is temperate/mesothermal with dry winters (Cwb). During the experimental period, mean temperatures were $21.3 ; 23.0 ; 21.8 ; 21.8$; and $21.9^{\circ} \mathrm{C}$ for the months of November and December 2007, January, February and March 2008 respectively, and total rainfall during the experimental period was of $987 \mathrm{~mm}$.

The hybrids used were categorized, based on productivity of the stalk and leaf components, in groups of high stalk/leaf ratio (AG1051, AG4051, P30F90, DOW2A525) and low stalk/leaf ratio (AG5011, DOW2C577, NB7315, DOW2B710) (Table 1).

Planting was undertaken on November 11, 2007 in the conventional planting system using $400 \mathrm{~kg} \mathrm{ha}^{-1}$ of the formula $08-28-16+0.5 \%$ zinc. When the plants had 2 to 3 fully expanded leaves, thinning was performed for the purpose of obtaining a stand of 60,000 plants ha ${ }^{-1}$. At the stage of 5 to 6 fully expanded leaves, fertilizer top dressing was made with $350 \mathrm{~kg} \mathrm{ha}^{-1}$ of the formula 30-00-20. For weed control, a pre-emergent herbicide was used with an atrazine + metolachlor base, as well as an application of

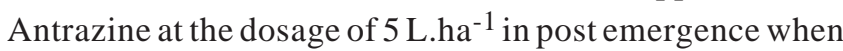
the plants had 5 fully expanded leaves. Other crop and plant health treatments were carried out at appropriate times in accordance with crop needs.

The experimental design used was randomized blocks in an 8 (hybrids) $\times 3$ (stages of maturity) factorial design, with three replications. Each plot consisted of six rows of $5 \mathrm{~m}$ length with $80 \mathrm{~cm}$ spacing for a total area of $24 \mathrm{~m}^{2}$. The two center rows were considered the useful area of each plot. Hybrids were harvested at the following stages of grain maturity: reduction of the milk line to half of the kernel $(1 / 2 \mathrm{ML})$, three-quarters milk line $(3 / 4 \mathrm{ML})$ and black layer (BL). Time of harvest was defined by visual evaluation of the milk line of the kernel in the middle of the ear from 20 days after flowering, and the plants were harvested at $20 \mathrm{~cm}$ from the ground. Fifteen plants from each plot were taken randomly and divided up into stalk, leaves, ear husk, cob and grains. Another fifteen plants from each plot, also taken randomly, were used to compose the whole plant sample. The parts were weighed and then the whole plant and its components (except for the grain) were chopped in a stationary chopper and homogenized for sampling. Grains were then frozen.

Samples of the entire plant and of each part of the plant were dried in a forced air laboratory oven at $55^{\circ} \mathrm{C}$ until constant weight, according to the methodology described by Gomes et al. (2004). Based on the DM, the productivity of each component was determined, as well as establishment of the stalk/leaf ratio, which consisted of the ratio between the productivity of the stalk and the productivity of the leaf. The stalk/leaf ratio was used for separation of the groups studied.

Afterwards, dried samples were ground in a Willey mill, with a $5 \mathrm{~mm}$ mesh screen for carrying out the in situ

Table 1 - Characteristics of the corn hybrids used in the experiment

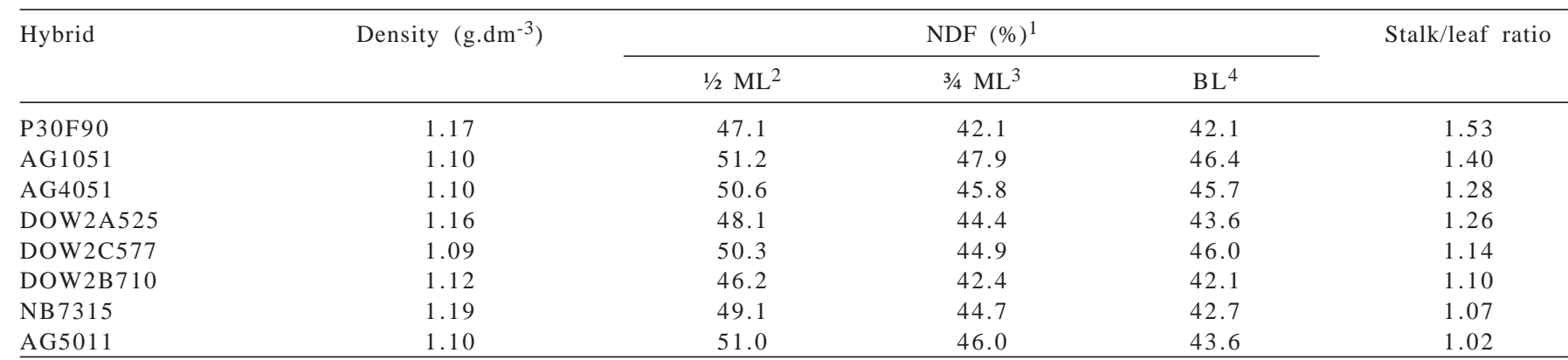

1 Neutral detergent fiber content.

${ }^{2}$ Hybrids harvested in the one-half milk line grain maturity stage.

${ }^{3}$ Hybrids harvested in the three-quarters milk line grain maturity stage.

${ }^{4}$ Hybrids harvested in the black layer grain maturity stage. 
degradability test of the DM, except for the grains that with the aid of a scalpel were cut in half still in a frozen state for determination of degradability in situ. For this evaluation, three cows with a ruminal cannula were used. One week before the beginning of the incubations and during the experimental period, animals received a diet composed of free choice corn silage and $8 \mathrm{~kg}$ of feed concentrate with a corn and soybean meal base in two daily feedings.

In situ degradability of the DM of the whole plant and of each part was determined by ruminal incubation in the period of 24 hours. Samples of $5 \mathrm{~g}$ per plot were incubated in polyester bags, with $9 \times 15 \mathrm{~cm}$ dimensions, corresponding to an $18.5 \mathrm{mg} \cdot \mathrm{cm}^{-2}$ ratio, except for the grains that were cut in two parts, simulating silage processing, where approximately $8 \mathrm{~g}$ of DM were inserted in the polyester bags. Small bags were placed within a tulle bag with the addition of weights to maintain them immersed in the rumen and, after being removed, the small bags were immediately placed in cold water. Then they were washed with light agitation in a tank system with an agitator, replacing the water until it looked transparent. Then the bags were once more placed in a laboratory oven at $55{ }^{\circ} \mathrm{C}$ until reaching constant weight.

In addition to the polyester bags containing each treatment, one empty bag was also incubated simultaneously in each period to estimate contamination by microbial DM. Microbial contamination by gram of bag was calculated and discounted from each incubation residue in proportion to the weight of the respective bag.

DM degradation (DEG24) was calculated as the disappearance of DM in 24 hours of incubation. The variable DEG24 is a result of the sum of DM degraded in the three cows, expressed in percentage of initial DM. The variables DEG24 of the whole plant (DEG24wp), stalk (DEG24s), leaf (DEG24l), husk(DEG24h), cob(DEG24c) and grain(DEG24g) were obtained. After drying and weighing, the residual NDF content of the parts and of the whole plant sample were determined. Furthermore, NDF and degradable NDF were determined for the whole plant and other components, except for the grain. NDF and the degradable NDF were obtained through non-sequential analysis using the rapid digestor for fiber in bags, Marconi brand, model MA-444, and neutral detergent solution in accordance with Van Soest et al. (1991). The bags used were of NWF (non-woven fabric) with a density of $100 \mathrm{~g} \cdot \mathrm{dm}^{-3}$. Degradable NDF was calculated by the disappearance of the NDF as a proportion of the initial NDF.

With the exception of the percentage of broken and lodged plants, the variables analyzed were in compliance with the presuppositions of analysis of variance and were performed by the GLM procedure of the SAS ${ }^{\circledR}$ (SAS Institute, 2001). The adjusted means were grouped in hybrids of high and low stalk/leaf ratio and another analysis was performed. Two orthogonal contrasts with 1 degree of freedom were tested for the harvest period: linear effect of maturity stage (1/2 ML versus BL) and quadratic effect of maturity stage (1/2 ML versus $3 / 4 \mathrm{ML}+\mathrm{BL})$. Estimates of Pearson phenotypic correlations were also obtained among the characteristics evaluated using the CORR procedure of the statistical package SAS ${ }^{\circledR}$ (SAS Institute, 2001).

\section{Results and Discussion}

There was a difference $(\mathrm{P}<0.01)$ in the stalk/leaf ratio between the groups evaluated. The HIGH group had, on average, a stalk/leaf ratio $21 \%$ greater than the LOW group (Table 2). A significant effect was observed $(\mathrm{P}<0.05)$ for stages of maturity over the DM contents of the whole plant and its parts. The DM percentage of the whole plant increased in a linear manner $(\mathrm{P}<0.01)$ throughout maturity. One-half milk line ( $\left.1 \frac{1}{2} \mathrm{ML}\right)$, three-quarters milk line $(3 / 4 \mathrm{ML})$ and black layer (BL) stages of maturity had average DM contents of the whole plant of 33.4; 39.4 and $52.1 \%$. In the stalk portion, the increase in DM was also linear $(\mathrm{P}=0.01)$ and its mean values were $22.4 ; 22.9$; and $26.2 \%$ in the $1 \frac{1}{2} \mathrm{ML}$, $3 / 4 \mathrm{ML}$ and $\mathrm{BL}$, respectively.

Table 2 - Means for stalk/leaf ratio, percentage of dry matter of the whole plant and of the parts of corn hybrids of high and low stalk/ leaf ratio harvested in three stages of maturity

\begin{tabular}{|c|c|c|c|c|c|c|c|c|c|}
\hline & \multicolumn{3}{|c|}{ High } & \multicolumn{3}{|c|}{ Low } & \multirow[b]{2}{*}{$\mathrm{SEM}^{1}$} & \multirow[b]{2}{*}{ Group $^{2}$} & \multirow[b]{2}{*}{$\mathrm{SM}^{3}$} \\
\hline & $1 / 2 \mathrm{ML}^{5}$ & $3 / 4 \mathrm{ML}^{6}$ & $\mathrm{BL}^{7}$ & $1 / 2 \mathrm{ML}^{5}$ & $3 / 4 \mathrm{ML}^{6}$ & $\mathrm{BL}^{7}$ & & & \\
\hline $\mathrm{SLR}^{4}$ & 1.3 & 1.4 & 1.5 & 1.1 & 1.1 & 1.1 & 0.1 & $<0.01$ & 0.45 \\
\hline Whole plant & 33.8 & 38.3 & 50.5 & 33.3 & 40.8 & 53.8 & 2.23 & 0.35 & $<0.01$ \\
\hline Stalk & 22.8 & 23.8 & 26.3 & 21.8 & 22.5 & 26.3 & 1.24 & 0.47 & 0.01 \\
\hline Leaf & 28.5 & 33.0 & 73.8 & 27.0 & 38.5 & 81.5 & 4.23 & 0.27 & $<0.01$ \\
\hline Husk & 33.3 & 40.5 & 68.3 & 33.8 & 48.5 & 69.0 & 3.59 & 0.31 & $<0.01$ \\
\hline Cob & 43.8 & 44.0 & 48.3 & 30.0 & 43.5 & 51.3 & 4.49 & 0.32 & 0.03 \\
\hline Grain & 57.0 & 64.5 & 72.5 & 55.8 & 66.3 & 73.3 & 1.27 & 0.69 & $<0.01$ \\
\hline
\end{tabular}

${ }^{1}$ Standard error of the mean. ${ }^{2,3}$ p value for effects of Group and SM (stage of maturity), respectively. ${ }^{4}$ Stalk/leaf ratio. ${ }^{5,6,7}$ Stage of maturity of grain at one-half milk line, three-quarters milk line and in the black layer, respectively. 
For leaf component, the increase in the DM content throughout the stages of maturity followed quadratic behavior $(\mathrm{P}<0.01)$, with average values of $27.7 ; 35.7$ and $77.6 \%$ for the cutting stages $1 / 2 \mathrm{ML}, 3 / 4 \mathrm{ML}$ and $\mathrm{BL}$, respectively. Mean percentages of DM for the husk part in the $1 / 2 \mathrm{ML}, 3 / 4 \mathrm{ML}$ and $\mathrm{BL}$ stages corresponded to the values of $33.5 ; 44.5$ and $68.6 \%$ and, just like in the leaf part, this increase had a quadratic effect $(\mathrm{P}<0.05)$. This quadratic effect in the DM content of the leaf and husk components indicates that for these parts, water loss was more intense between the $3 / 4$ ML to BL stages, probably because of the senescence process' being more intense in stages after $3 / 4$ ML. In the cob component, the mean DM contents for the $1 / 2 \mathrm{ML}, 3 / 4 \mathrm{ML}$ and BL stages of maturity were 36.8; 43.7 and $49.7 \%$ respectively. In relation to the grain, the mean DM contents were $57 \%(1 / 2 \mathrm{ML}), 64.5 \%(3 / 4 \mathrm{ML})$ and $72.5 \%(\mathrm{BL})$. The increase in these contents had linear behavior $(\mathrm{P}<0.05$ and $\mathrm{P}<0.01$ respectively) and, just like in the whole plant and other parts, there was no difference between the groups evaluated. Evaluating Leafy and conventional hybrids, Ma et al. (2006) found different results for this study. For these authors, hybrids with greater proportion of leaves in the DM had a less accentuated moisture decrease, showing a more prolonged optimal cutting period.

Gomes et al. (2004) and Mendes et al. (2008) observed a high correlation between the 24 hour incubation period and the effective degradability, indicating the possibility of evaluating the degradability of DM in the 24-hour incubation period. For this characteristic, no significant effect $(\mathrm{P}<0.05)$ of the group source on the plant components was observed. Stages of maturity influenced $(\mathrm{P}<0.05)$ the degradability of the whole plant, with values of 54.5; 53.4 and $49.5 \%$ for the $1 / 2 \mathrm{ML}, 3 / 4 \mathrm{ML}$ and BL stages, respectively, as well as the leaf, husk and grain parts (Table 3).

Although studies highlight the qualities of the leafy materials (Johnson et al., 1999; Clark et al., 2002) for the hybrids evaluated in this study, the results indicate that the difference in the stalk/leaf ratio did not result in greater degradability of the forage. However, even in evaluations with leafy hybrids, it is possible to find results in which the greater proportion of leaves also did not affect forage quality (Nennich et al., 2003; Benefield et al., 2006). Verbic et al. (1995) and Masoero et al. (2006) attributed the differences in the quality of the whole plant to the quality of its parts, and not to their proportion in the DM.

In the evaluation of degradability of the stalk part, there was no significance $(\mathrm{P}<0.05)$ for the source group and stages of maturity, with a mean of $36.6 \%$. In contrast to that found in this study, Verbic et al. (1995) found variations greater than $30 \%$ for effective degradability of the DM of stalks among corn hybrids.

Evaluating breeding lines of different populations, Jung et al. (1998) and Menchin et al. (2000) found "conventional” materials with stalk quality characteristics very close to those observed in breeding lines that contain the brown midrib (bm3) gene. The high degree of genetic variability for quality characteristics of the stalk cell wall enables an optimistic outlook for development of corn hybrids for silage (Jung \& Casler, 2006). Zeoula et al. (2003) pointed out the importance of the use of corn hybrids with good digestibility of the stalk part, with possible savings of up to $1.5 \mathrm{~kg}$ of concentrate/animal/day.

Johnson et al. (1999) and Masoero et al. (2006) reported a decrease in stalk degradability with an advance in maturity. After flowering, Kruse et al. (2008) stated that the loss in quality of the vegetative parts is due to the accumulation of cell wall components, but especially because of the remobilization of non-structural carbohydrates to ears. In this study, in contrast to the whole plant and the leaf, husk, and grain components, the advance in maturity led to less accentuated losses in stalk degradability.

The degradability of the leaf part was influenced by the stages of maturity $(\mathrm{P}<0.05)$ and the mean values in the $1 / 2 \mathrm{ML}, 3 / 4 \mathrm{ML}$ and BL stages were 50.3; 40.8 and 36.6\% respectively. Verbic et al. (1995) attributed the differences found in effective degradability of leaves to the variations

Table 3 - Degradability of the whole plant and of the parts of corn hybrids with high and low stalk/leaf ratio harvested at three stages of maturity

\begin{tabular}{|c|c|c|c|c|c|c|c|c|c|}
\hline & \multicolumn{3}{|c|}{ High } & \multicolumn{3}{|c|}{ Low } & \multirow[b]{2}{*}{ SEM $^{1}$} & \multirow[b]{2}{*}{ Group $^{2}$} & \multirow[b]{2}{*}{$\mathrm{SM}^{3}$} \\
\hline & $1 / 2 \mathrm{ML}^{4}$ & $3 / 4 \mathrm{ML}^{5}$ & $\mathrm{BL}^{6}$ & $1 / 2 \mathrm{ML}^{4}$ & $3 / 4 \mathrm{ML}^{5}$ & $\mathrm{BL}^{6}$ & & & \\
\hline & \multicolumn{9}{|c|}{$\%$} \\
\hline Whole plant & 54.0 & 53.9 & 49.9 & 55.1 & 53.0 & 49.2 & 1.06 & 0.84 & $<0.01$ \\
\hline Stalk & 39.3 & 41.0 & 33.1 & 38.4 & 35.6 & 30.6 & 4.04 & 0.39 & 0.19 \\
\hline Leaf & 50.9 & 42.0 & 37.5 & 49.8 & 39.7 & 35.8 & 1.81 & 0.26 & $<0.01$ \\
\hline Husk & 46.6 & 37.7 & 30.4 & 42.6 & 33.8 & 31.3 & 1.86 & 0.15 & $<0.01$ \\
\hline Cob & 30.0 & 29.1 & 27.9 & 27.6 & 25.9 & 21.8 & 2.36 & 0.06 & 0.26 \\
\hline Grain & 33.3 & 21.7 & 17.6 & 32.4 & 20.3 & 18.7 & 0.91 & 0.55 & $<0.01$ \\
\hline
\end{tabular}

${ }^{1}$ Standard error of the mean, ${ }^{2}$ Group $=P$ for effects of the stalk/leaf ratio. ${ }^{3} \mathrm{SM}=P$ for effects of stage of maturity. ${ }^{4,5}, 6$ Stage of maturity of the grain at the one-half milk line three-quarters milk line and at the black layer, respectively. 
in the quality of the part and not to its proportion in the DM. In a more pronounced way than that observed in the stalk and whole plant, the remobilization of photoassimilates to ears and the accumulation of materials in the cell wall caused a decrease in the degradability of the leaf component. However, from the components evaluated, the leaf part was that which showed the greatest degradability values.

The loss in quantity and quality of leaves seems to be one of the key points in maintenance of forage quality, with an accentuated loss of leaves being observed as of the $1 / 2 \mathrm{ML}$ stage of maturity. Roth \& Lauer (2008) observed that the loss of the vegetative component of better quality was capable of reducing the degradable NDF of the whole plant and milk production per area. It is worth stressing that characteristics such as stay green do not necessarily confer good quality to the forage. Ettle \& Schwarz (2003) reinforce that efforts seeking to increase the quality of the bulky part using this characteristic were not very successful. In this context, important characteristics such as adaptability, cycle, and disease resistance must not be neglected because they contribute to leaf maintenance.

Degradability of the husk was influenced by the stages of maturity $(\mathrm{P}<0.01)$ with mean values of $44 \%(1 / 2 \mathrm{ML}), 35.4 \%$ $(3 / 4 \mathrm{ML})$ and $30.8 \%(\mathrm{BL})$. In contrast with the leaf, husk, and grain parts, the stages of maturity did not alter the cob degradability. It can be stated that once in the $1 / 2 \mathrm{ML}$ stage, the cob component had high levels of indigestible components.

Degradability of the grain part did not undergo effects of the high and low stalk/leaf ratio groups; however, it was affected in a significant way by the stages of maturity. The mean values for degradability in the $1 / 2 \mathrm{ML}, 3 / 4 \mathrm{ML}$ and $\mathrm{BL}$ stages of maturity were 32.8 ; 21 and $18.1 \%$.
In the stalk, leaf, husk, cob, and grain parts, the losses in degradability throughout the stages evaluated were 15.8; $27.0 ; 34.0 ; 6.8$ and $51.0 \%$, respectively. The expressive loss in the quality of the component of greatest proportion in the DM (grain) is also one of the key points to maintenance of forage quality. Along with the accumulation of grain and the reduction in its quality, there was also an accentuated loss in the quality of the vegetative parts. The increase in the grain proportion was capable of leading to a dilution in the NDF contents; however, it did not support maintenance in the quality of the whole plant, which reduced the degradability and degradable NDF (Table 4).

The concentrations of NDF and degradable NDF of the whole plant were influenced by the stages of maturity $(\mathrm{P}<0.01)$. The NDF content of the whole plant reduced with the advance of the stages of maturity, presenting means of 49.2; 44.7 and $44 \%$ in the $1 / 2 \mathrm{ML}, 3 / 4 \mathrm{ML}$ and BL, respectively (Table 3). In accordance with Bal et al. (1997), little does the NDF content between the $3 / 4 \mathrm{ML}$ and BL stages change, which may be observed in this study. Some studies show that the NDF values decrease with the advance of maturity (Di Marco et al., 2002; Filya, 2004) due to the effect of dilution by the accumulation of starch. In contrast, it is possible to find results in which NDF has an increase throughout maturity (Estrada-Flores et al., 2006; Vilela et al. 2008). An explanation for the difference in the trends of NDF accumulation is the amplitude of the stages of maturity in which the materials are harvested. In general, for stages of maturity in which starch accumulation is less intense, there is an increase in the NDF contents, whereas in the stages of greater increase in the DM of the grain, starch accumulation is sufficient for maintenance or reduction of the NDF contents.

Table 4 - Percentage of neutral detergent fiber and degradable neutral detergent fiber of the whole plant and of the parts of corn hybrids with high and low stalk/leaf ratio harvested at three stages of maturity

\begin{tabular}{|c|c|c|c|c|c|c|c|c|c|}
\hline & \multicolumn{3}{|c|}{ High } & \multicolumn{3}{|c|}{ Low } & \multirow[b]{2}{*}{ SEM $^{1}$} & \multirow[b]{2}{*}{ Group $^{2}$} & \multirow[b]{2}{*}{$\mathrm{SM}^{3}$} \\
\hline & $1 / 2 \mathrm{ML}^{4}$ & $3 / 4 \mathrm{ML}^{5}$ & $\mathrm{BL}^{6}$ & $1 / 2 \mathrm{ML}^{4}$ & $3 / 4 \mathrm{ML}^{5}$ & $\mathrm{BL}^{6}$ & & & \\
\hline & \multicolumn{9}{|c|}{$\mathrm{NDF} \%{ }^{7}$} \\
\hline Whole plant & 49.3 & 45.0 & 44.4 & 49.2 & 44.5 & 43.6 & 0.98 & 0.55 & $<0.01$ \\
\hline Stalk & 71.9 & 70.8 & 73.7 & 74.4 & 73.7 & 77.3 & 3.51 & 0.30 & 0.64 \\
\hline Leaf & 73.4 & 74.2 & 80.5 & 73.0 & 76.1 & 81.0 & 1.74 & 0.66 & $<0.01$ \\
\hline Husk & 77.4 & 82.9 & 86.8 & 83.0 & 87.3 & 86.5 & 2.34 & 0.11 & 0.03 \\
\hline \multirow[t]{2}{*}{ Cob } & 82.4 & 84.1 & 88.0 & 80.6 & 84.6 & 88.4 & 1.65 & 0.84 & $<0.01$ \\
\hline & \multicolumn{9}{|c|}{ Degradable $\mathrm{NDF}^{8}$} \\
\hline Whole plant & 29.0 & 26.1 & 23.1 & 28.6 & 24.2 & 22.6 & 1.2 & 0.38 & $<0.01$ \\
\hline Stalk & 20.6 & 22.7 & 15.7 & 22.3 & 18.7 & 16.9 & 2.2 & 0.86 & 0.06 \\
\hline Leaf & 40.7 & 31.6 & 32.2 & 39.1 & 30.8 & 29.8 & 1.5 & 0.20 & $<0.01$ \\
\hline Husk & 33.6 & 28.2 & 25.2 & 33.7 & 28.0 & 25.8 & 1.6 & 0.89 & $<0.01$ \\
\hline Cob & 20.1 & 21.7 & 22.9 & 15.5 & 18.2 & 16.2 & 2.2 & 0.01 & 0.62 \\
\hline
\end{tabular}

${ }^{1}$ Standard error of the mean. ${ }^{2}$ Group $=P$ for effects of the stalk/leaf ratio. ${ }^{3} \mathrm{SM}=P$ for effects of the stage of maturity. ${ }^{4,5,6}$ Stage of maturity of the grain at the one-half milk line, three-quarters milk line and at the black layer, respectively. ${ }^{7,8}$ Neutral detergent fiber content and degradable neutral detergent fiber content. 
In the stalk part, the NDF content did not undergo influence of the groups and stages of maturity and had values of 73 ( $1 / 2 \mathrm{ML}), 72.2$ ( $3 / 4 \mathrm{ML})$ and $75.5 \%$ (BL). For the other parts, there was an increase in the NDF contents with increasing maturity (Table 3). Masoero et al. (2006) observed an increase of NDF in the stalk in the R4 to R6 stages, with a decrease in the in vitro degradability of the stalk part also being observed. Estrada-Flores et al. (2006), evaluating different growth stages, also observed the same behavior. These results suggest that the stalk quality data are quite divergent and dependent on the prevalent environmental conditions.

In regard to the degradable NDF content of the stalk, it may be inferred that it underwent the influence of the stages of maturity with $94 \%$ probability. In the $1 \frac{1}{2} \mathrm{ML}, 3 / 4 \mathrm{ML}$ and BL stages, the degradable NDF values were 28.8; 25.1 and $22.8 \%$, respectively. Along with the cob part, the stalk part had the lowest values for degradable NDF (Table 4).

For the leaf part, there was a significant effect $(\mathrm{P}<0.01)$ of the stages of maturity on the NDF of the leaf and degradable NDF with values of $72.7 ; 75.1 \%(3 / 4 \mathrm{ML})$ and 80.7\% (BL) for the NDF and 39.9\% ( $\left.1 \frac{1}{2} \mathrm{ML}\right), 31.2 \%(3 / 4 \mathrm{ML})$ and 31\% (BL) for degradable NDF. Among the components, the leaf part had the greatest values of degradable NDF, which is in accordance with the results obtained by Tolera \& Sundstùlc (1999) and Tang et al. (2008). Senescence reduced the degradable NDF and increased the NDF content for remobilization of photoassimilates for the grain. Similar behavior was also observed by Masoero et al. (2006) and Kruse et al. (2008).

A significant effect was observed for the stages of maturity on the NDF of the husk $(\mathrm{P}<0.05)$ and degradable NDF of the husk $(\mathrm{P}<0.01)$. The means of the husk's NDF at $1 / 2 \mathrm{ML}, 3 / 4 \mathrm{ML}$ and BL stages of maturity were $80.2 \%, 85.1 \%$ and $86.6 \%$ respectively (Table 3 ). The increase in the NDF content of the husk was approximately $8 \%$ throughout the stages evaluated. For the degradable NDF of the husk, the following mean values were observed: 33.6\% (1/2 ML), 28.1\% ( $3 / 4 \mathrm{ML}$ ) and $25.5 \%$ (BL). Mean reduction throughout the stages evaluated was $24 \%$.

Verbic et al. (1995) found variations among hybrids of $39 \%$ to $45 \%$ for in vitro degradability and 73 to $79 \%$ for NDF contents of husk of hybrids harvested at the one-half milk line; however, these differences were not attributed to ratios among the parts. In this study, the husk part obtained degradability and degradable NDF results above the stalk and cob parts, and only the leaf part had quality greater than the husk. Estrada-Flores et al. (2006) explain the quality of the husk component through the low concentration of ADF (acid detergent fiber).
Regarding the cob component, there was a significant effect $(\mathrm{P}<0.01)$ of the stages of maturity on the NDF content, with mean values for $1 / 2 \mathrm{ML}, 3 / 4 \mathrm{ML}$ and $\mathrm{BL}$ of $81.5 ; 84.3$ and $88.2 \%$, respectively (Table 4 ). The degradable neutral detergent fiber of the cob part was influenced $(\mathrm{P}<0.05)$ by the high and low stalk/leaf ratio groups, with values of $21.5 \%$ for the high and $16.6 \%$ for the low stalk/leaf ratio group. The non-significant effect of the stages of maturity on the degradable NDF of the cob may be explained by the fact that component has low quality fiber, bearing in mind that the cob had the lowest degradable NDF content. Probably because of the small proportion of the cob component in the DM, the difference in the degradable NDF values between the groups was not sufficient to alter the fiber quality of the whole plant.

It may be questioned that even with the effort of using hybrids in this experiment that fit within different stalk/leaf ratio groups, there may be differences, in the universe of hybrids made available in the seed market, in the stalk/leaf ratio that extrapolate that found in this study, and which may generate an effect for this factor. This hypothesis is not very probable because the lack of significance by the $\mathrm{F}$ test is quite consistent with $\mathrm{p}$ values always greater than 0.38 for the variables related to the whole plant. For that reason, it is believed that the non-significance for the stalk/leaf ratio source groups, for most of the variables, indicates that plant quality is associated with the quality of its components and not their proportion in the DM.

Analyzing the correlation coefficients among the variables, a direct correlation of degradability is observed with the degradable NDF, degradability of the stalk, leaf, husk, and grain parts (Table 5). An inverse correlation is also noted between the NDF content and degradability of the whole plant. This indicates that improvement in the quality of any one of these components will bring significant results to the final quality of the forage. In addition to low proportion in the DM, the cob was also of little importance in the quality of the forage; and, among all the parts, the only degradability that did not correlate with that of the whole plant was the degradability of the cob part.

Fonseca (2000) observed that among all the characteristics which determine forage quality, the NDF content was the variable that was most correlated with quality. For that reason, materials with low contents of this fiber are sought. It should be emphasized that this component has a $40 \%$ to $55 \%$ share in the entire DM. This shows that materials with good NDF quality can have a large impact on forage quality. Perhaps it is for that reason that the correlation between degradability and degradable NDF showed the 
Table 5 - Correlations between degradability of the whole plant and the parts, lodged and broken plants, neutral detergent fiber contents and degradable neutral detergent fiber contents of corn hybrids harvested at three stages of maturity

\begin{tabular}{|c|c|c|c|c|c|c|}
\hline & Whole plant & Stalk & Leaf & Husk & Cob & Grain \\
\hline $\mathrm{NDF}^{1}$ & $-0.61 * *$ & $-0.89 * * *$ & $-0.79 * * *$ & $-0.77 * * *$ & $-0.61 * *$ & - \\
\hline Degradable $\mathrm{NDF}^{2}$ & $0.68 * *$ & $0.71 * *$ & $0.89 * * *$ & $0.81 * * *$ & $0.73 * *$ & - \\
\hline Lodged and broken & $-0.14 \mathrm{NS}$ & -0.13 NS & -0.16 NS & -0.13 NS & $0.16 \mathrm{NS}$ & -0.14 NS \\
\hline Whole plant & - & $0.65 * *$ & $0.63 * *$ & $0.70 * *$ & $0.17 \mathrm{NS}$ & $0.57 * *$ \\
\hline Stalk & & - & $0.53 * *$ & $0.49 *$ & $0.27 \mathrm{NS}$ & $0.26 \mathrm{NS}$ \\
\hline Leaf & & & - & $0.86 * * *$ & $0.50 *$ & $0.87 * * *$ \\
\hline Husk & & & & - & $0.50 *$ & $0.85 * * *$ \\
\hline Cob & & & & & - & $0.36 \mathrm{NS}$ \\
\hline
\end{tabular}

greatest correlation coefficient (r) when compared with association with the NDF. The r values for degradability and NDF and degradable NDF were 0.61 and 0.68 , respectively. This parameter may be used in silage hybrid breeding programs. However, the association of this variable with animal performance parameters is also quite interesting since some authors associate the increase in milk production to an increase in the passage and consumption rate of DM rather than to greater energy concentration in the forage (Oba \& Allen, 2000; Frey et al., 2004).

The degradability of the stalk, leaf, husk, and cob parts was also inversely correlated with the NDF content and directly with the degradable NDF (Table 5). Only for the stalk part did NDF obtain a correlation of greater magnitude with degradability if compared to degradable NDF. Direct correlation among the degradability of the parts confirms the hypothesis brought up by He et al. (2003) that techniques seeking fiber improvement are promising because they are capable of improving the quality of all components.

Association between resistance to lodging and bromatological quality of the stalk has not been explored to a great extent, and, in an empirical manner, technicians and researchers suggest that the quality of the forage, and especially of the stalk part, is involved with the increase of characteristics that confer resistance to lodging and to the action of pathogenic agents. Albrecht et al. (1986) evaluated two populations before and after three recurrent selection cycles with a view toward increasing resistance to lodging and stalk rot. In both situations, total concentrations of non-structural carbohydrates increased and were sufficient for promoting dilution in the stalk fibers, also increasing the in vitro degradability of this part. In this study, the degradability, NDF, and degradable NDF of the stalk part did not have any relation to the number of lodged plants, which does not permit the establishment of a functional relationship between lodging and stalk quality (Table 5).

\section{Conclusions}

The quality of corn forage is more dependent on the quality of the stalk, leaf, husk, cob, and grain components than on the proportion of these parts in the dry matter. The advance of maturity reduces the forage quality of the whole plant and its components, except for the stalk and cob, which have low quality from the $1 / 2$ milk line stage. Stalk/leaf ratio does not influence forage quality.

\section{Acknowledgments}

Research funded by Coordenação de Aperfeiçoamento de Pessoal de Nível Superior (Capes) and Fundação de Amparo à Pesquisa do Estado de Minas Gerais (Fapemig).

\section{References}

ALBRECHT, K.A.; MARTIN, M.J.; RUSSEL, W.A. et al. Chemical and in vitro digestible dry matter composition of maize stalks after selection for stalk strength and stalk-rot resistance. Crop Science, v.26, n.1, p.1051-1055, 1986.

ALlEN, M.S.; COORS, J.G.; ROTH, G.W. In: BUXTON, D.R.; MUCK, R.E.; HARRISON, J.H. (Eds.). Silage science and technology. Madison: ASA-CSSA-SSSA. 2003. p.547-608.

BAL, M.A.; COORS, J.G.; SHAVER, R.D. Impact of maturity of corn for use as silage in the diets of dairy cows on intake, digestion, and milk production Journal of Dairy Science, v.80, n.84, p.2497-2503, 1997.

BALLARD, C.S.; THOMAS, E.D.; TSANG, D.S. et al. Effect of corn silage hybrid on dry matter yield, nutrient composition, in vitro digestion, intake by dairy heifers, and milk production by dairy cows. Journal of Dairy Science, v.84, n.2, p.442-452, 2001.

BENEFIELD, B.C.; LIÑEIRO, M.; IPHARRAGUERRE, I.R. et al. Nutridense corn grain and corn silage for dairy cows. Journal of Dairy Science, v.89, p.1571-1579, 2006.

CLARK, P.W.; KELM, S.; ENDRES, M.I. Effect of feeding a corn hybrid selected for leafiness as silage or grain to lactating dairy cattle. Journal of Dairy Science, v.85, n.3, p.607-612, 2002.

DI MARCO, O.N.; AELLO, M.S.; NOMDEDEU, M. Effect of maize crop maturity on silage chemical composition and digestibility (in vivo, in situ and in vitro). Animal Feed Science and Technology, v.99, p.37-43, 2002. 
ESTRADA-FLORES, J.G.; GONZÁLEZ-RONQUILLO, M.; MOULD, F.L. et al. Chemical composition and fermentation characteristics of grain and different parts of the stover from maize land races harvested at different growing periods in two zones of central Mexico. Animal Science, v.82, n.6, p.845-852, 2006.

ETTLE, T.; SCHWARZ, F.J. Effect of maize variety harvested at different maturity stages on feeding value and performance of dairy cows. Animal Research, v.52, n.4, p.337-349, 2003.

FILYA, I. Nutritive value and aerobic stability of whole crop maize silage harvested at four stages of maturity. Animal Feed Science and Technology, v.116, n.1, p.141-150, 2004.

FREY, T.J.; COORS, J.G.; SHAVER, R.D. et al. Selection for silage quality in the Wisconsin quality synthetic and related maize populations. Crop Science v.44, n.4, p.1200-1208, 2004.

FONSECA, A.H. Características químicas e agronômicas associadas à degradabilidade da silagem de milho. 2000. 93f. Dissertação (Mestrado em Fitotecnia) - Universidade Federal de Lavras, Lavras.

GOMES, M.S.; VON PINHO, R.G.; RAMALHO, M.A.P. et al. Variabilidade genética em linhagens de milho nas características relacionadas com a produtividade de silagem. Pesquisa Agropecuária Brasileira, v.39, n.9, p.879-885, 2004.

HE, X.; HALL, M.B.; GALLO-MEAGHER, M. et al. Improvement of forage quality by downregulation of maize $O$ methyltransferase. Crop Science, v.43, p.2240-2251, 2003.

HUNT, C.W.; KEZAR, W.; VINANDE, R. Yield, chemical composition, and ruminal fermentability of corn whole plant, ear, and stover as affected by maturity. Journal of Production Agriculture, v.2, n.7, p.357-361, 1998.

JOHNSON, L.; HARRISON, J.H.; HUNT, C. et al. Nutritive value of corn silage as affected by maturity and mechanical processing: a contemporary review. Journal of Dairy Science, v.82, p.2813-2825, 1999.

JUNG, H.G.; CASLER, M.D. Maize stem tissues: impact of development on cell wall degradability. Crop Science, v.46, n.1, p.1801-1809, 2006.

JUNG, H.G.; MORRISON, T.A.; BUXTON, D.R. Degradability of cell-wall polysaccharides in maize internodes during stalk development. Crop Science, v.38, n.1, p.1047-1051, 1998.

KRUSE, S.; HERRMANN, A.; KORNHER, A. et al. Evaluation of genotype and environmental variation in fiber content of silage maize using a model-assisted approach. European Journal Agronomy, v.28, n.1, p.210-223, 2008.

MA, B.L.; SUBEDI, K.D.; STEWART, D.W. et al. Dry matter accumulation and silage moisture changes after silking in leafy and dual-purpose corn hybrids. Agronomy Journal, v.98, n.2, p.922-929, 2006.

MASOERO, F.; MOSCHINI, M.; FUSCONI, G. et al. Raw, extruded and expanded pea (Pisum sativum) in dairy cows diets. Italy Journal Animal Science, v.5, n.1, p.237-247, 2006.
MÉNCHIN, V.; ARGILliER, O.; MENANTEAU, V. et al. Relationship of cell wall composition to in vitro cell wall digestibility of maize inbred line stems. Journal of the Science of Food and Agriculture, v.80, n.5, p.574-580, 2000.

MENDES, M.C.; VON PINHO, R.G.; PEREIRA, M.N. et al. Avaliação de híbridos de milho obtidos do cruzamento entre linhagens com diferentes níveis de degradabilidade da matéria seca. Bragantia, v.67, n.2, p.285-297, 2008.

NENNICH; T.D.; LINN, J.G.; JOHNSON, D.G. et al. Comparison of feeding corn silages from leafy or conventional corn hybrids to lactating dairy cows Journal of Dairy Science, v.86, n.9, p.2932-2939, 2003.

NUSSIO, L.G. Produção de silagem de alta qualidade. In: CONGRESSO NACIONAL DE MILHO E SORGO, 19., 1992, Porto Alegre. Conferências... Porto Alegre: SAA/SCT/ABMS/Emater-RS/ Embrapa-CNPMS, 1992. p.155-175.

OBA,M.; ALLEN, M.S. Effects of brown midrib 3 mutation in corn silage on productivity of dairy cows fed two concentrations of dietary neutral detergent fiber. 1. Feeding behavior and nutrient utilization. Journal of Dairy Science, v.83, n.6, p.1333-1341, 2000.

ROTH, G.W.; LAUER J.G. Impact of defoliation on corn forage quality. Agronomy Journal, v.100, n.1, p.651-657, 2008.

STATISTICAL ANALYSES SYSTEM - SAS. SAS/STAT User's guide. 8.1 ed. Cary: SAS Institute, 2001. 1028p

TANG, S.X.; GAN, J.; SHENG L.X. et al. Morphological fractions, chemical composition and in vitro fermentation characteristics of maize stover of five genotypes. Animal Science, v.2, n.12, p.1772-1779, 2008.

TOLERAA, A.; SUNDSTÙLC, F. Morphological fractions of maize stover harvested at different stages of grain maturity and nutritive value of different fractions of the stover. Animal Feed Science and Technology, v.81, n.1-2, p.1-16, 1999.

VAN SOEST, P.J.; ROBERTSON, J.B.; LEWIS, B.A. Methods for dietary fiber, neutral detergent fiber and nonstarch polysaccharides in relation to animal nutrition. Journal of Dairy Science, v.74, n.1, p.3583-3597, 1991.

VERBIC, J.; STEKAR, J.M.A.; CEPON, M.R. Rumen degradation characteristics and fibre composition of various morphological parts of different maize hybrids and possible consequences for breeding. Animal Feed Science and Technology, v.54, n.1, p.133-148, 1995.

VILELA, H.H.; REZENDE, A.V.; VIEIRA, P.F. et al. Valor nutritivo de silagens de milho colhido em diversos estádios de maturação. Revista Brasileira de Zootecnia, v.37, n.4, p.1192-1199, 2008.

ZEOULA, L.M.; BELEZE, J.R.F.; CECATO, U. et al. Avaliação de cinco híbridos de milho (Zea mays, $L$.) em diferentes estádios de maturação. 4. Digestibilidade da matéria seca, matéria orgânica e fibra em detergente neutro da porção vegetativa e planta inteira. Revista Brasileira de Zootecnia, v.32, n.3, p.567-575, 2003. 